\title{
Implementation of Biopesticides to Control Phytophthora palmivora Butl. and Conopomorpha cramerella Snell. on Cacao in South Halmahera
}

\author{
Fredy Lala ${ }^{1, *}$, Hermawati Cahyaningrum ${ }^{1}$, Agus Hadiarto $^{1}$, Bram Brahmantiyo ${ }^{1}$ \\ ${ }^{I}$ Assessment Institute for Agriculture Technology North Maluku, Tidore, Indonesia \\ "Corresponding author. Email: lalafredy@ymail.com
}

\begin{abstract}
One of the causes of low productivity of cocoa due to Conopomorpha cramerella known as cocoa pod borer (CPB) and black pod rot (BPR) caused by Phytophthora palmivora. Biopesticides consisted of Beauveria bassiana and kaolin was introduced to protect the surface of cocoa pods from CPB and BPR. The research was conducted in the District of Bacan, South Halmahera Regency, North Maluku from April to December 2017. The research was design using randomized block design (RBD), consisting of four treatments as follows: Bio-K (biopesticides), plastic (0.24 mm transparent plastic), metallaxyl (RG), and farmer technique as a control treatment with five replications and thirty plants per replications. Therefore, in the field were 150 plants. Application of biopesticides performed at two-weeks intervals since the pods measurement from 8 $10 \mathrm{~cm}$ until harvest time. The observational variables consisted of the symptoms of CPB and BPR, disease incidence, number of CPB infestation, and number of harvested pods. Results showed that biopesticide treatment significantly reduced pod damage by CPB while the disease incidence of BPR was not significantly different from metalaxyl which was the best treatment. The average decreases in the number of cacao pod respectively were Bio-K (7.69\%), plastic (14.29\%), metalaxyl $(27.78 \%)$ and control $(62.50 \%)$. The study implies that Bio-K was effective in protecting cocoa pods from $C$. cramerella infestation and $P$. palmivora infection.
\end{abstract}

Keywords: cocoa, cocoa pod borer, black pod rot, biopesticide

\section{INTRODUCTION}

The cocoa tree, Theobroma cacao (Malvaceae) originated from South America [1] and is now grown largely across wet tropical areas of America, Africa and Asia [2]. Cocoa beans, extracted from the cocoa pod of the tree, are an important cash crop across these regions [2,3]. The butter and powder produced from cocoa beans are used mainly in chocolate manufacture [4]. The productivity of cocoa in North Maluku was about $730 \mathrm{~kg} / \mathrm{ha} /$ year under the national productivity $(900 \mathrm{~kg} / \mathrm{ha} /$ year $)$ while the potential production can reaches $2,000 \mathrm{~kg} / \mathrm{ha} /$ year [5]. One of the causes of low productivity of cocoa due to Conopomorpha cramerella known as cocoa pod borer (CPB) and black pod rot (BPR) caused by Phytophthora palmivora [6]. C. cramerella became a major pest of cocoa in Southeast Asia in the mid 1980's and since early this century, is considered the main pest threat for cocoa production in Indonesia, the Philippines and Malaysia [7]. The plants that are attacked by CPB and BPR didn't get special treatment, so they become a source of inoculum of the pathogen and breeding ground for the insect. In addition, during the vegetative and generative phase, the plant experience nutritional loss [8]. The cocoa was still attacked by both CPB and BPR despite the maintenance treatment of plant on the site such as pruning and sanitation.
Many cocoa producers offset the risk of loss from pests and disease in cocoa by diversifying into various other crops as a source of income [9]. In parts of the world farmers are dependant on government supplied inputs including improved varieties of cocoa seedlings, fertilisers and even the application of pesticides $[4,10]$. Disease intensity range of BPR can reach $47-82 \%$ while $\mathrm{CPB}$ was more than $30 \%$. In Papua New Guinea $C$. cramerella was not considered a pest until an outbreak in 2006, in the East New Britain Province. Two eradication programs were attempted but were unsuccessful $[11,12]$. In situations of severe infestation, cocoa yield has reportedly been reduced by $60-84 \%$, with dry bean quality also affected. Cocoa crop loss due to $C$. cramerella in Asia early this century was estimated at US\$500 million/annum [7]. Once inside the pod, larvae feed on the placenta and pulp that supply nutrients to the beans and the interruption of bean development causes clumping of beans and hardening of the pod resulting in harvesting and processing difficulties [13]. Pathogens are estimated to reduce global cocoa yields by at least $20 \%$ annually however under the right conditions are able to completely destroy a crop [14]. The most significant pathogens are Phytophthora species, including the ubiquitous $P$. palmivora and Phytophthora megakarya in West Africa, that together cause losses of 20$30 \%$ [15].

The chemical control often not optimal because the application of pesticides depends on the availability of capital. Chemical insecticide applications also require high 
costs, and considered ineffective because it can only kill $\mathrm{CPB}$ imagos, have a negative impact on environment, animals and humans [16]. The pesticides that not hit the target were discharged into the air will deposit on the soil and potentially endanger other biophysical elements such as the death of certain species also air and soil pollution. Utilization of biological agents for the control of CPB is a pest control method that has proven effective in controlling a variety of pests and diseases $[17,18]$.

Control of IPM involves components of biological agents, resistant planting materials, and environmental management based on the ecological, economic, and sociological considerations to support environmentally friendly farming systems $[19,20,21,22,23]$. CPB control strategies can be done through technical culture approach, mechanical, chemical, as well as the use of resistant clones [24]. The study on various control techniques, including the utilization of a mechanical protection combined with biological agents, such as biokaolin, is important to be done, as alternative strategies for CPB control. Biokaolin is a mechanical protection, which uses kaolin mineral layers and entomopathogenic fungi Beauveria bassiana, which will grow and develop on the surface of the fruits or leaves. Kaolin layer and entomopathogenic fungi on the surface of the fruits or leaves can be a double function as a mechanical barrier and biological control [25]. Condisered the ineffectiveness of chemical pesticides and their negative impact on the environment, it is necessary to innovate a biopesticides technology that is environmentally friendly. Therefore, the extent of biopesticides technology can protect the plants against $\mathrm{CPB}$ and BPR as well as to increase the productivity that needs to be investigated.

\section{METHODS}

The research was conducted in Makean, District of Bacan, South Halmahera Regency, North Maluku, Indonesia from April to December 2017. The location and farmers selection was done by purposively that it's an endemic area of CPB and BPR. The study was undertaken in farmer fields to solve specific problems. The research was design using randomized block design (RBD), consisting of four treatments as follows: Bio-K (biopesticides), plastic (0.24 $\mathrm{mm}$ transparent plastic), RG (metalaxyl), and farmer technique as a control treatment with five replications and thirty plants per replications. Therefore, in the field were 150 plants. Application of biopesticides performed at twoweeks intervals since the pods' measurement from $8-10$ $\mathrm{cm}$ until harvest time. Knapcask sprayer was use for the application of biopesticides and metalaxyl. The observational variables consisted of the symptoms of CPB and $\mathrm{BPR}$, disease incidence, number of $\mathrm{CPB}$ infestation, and number of harvested pods. These variables were observed and counted when the pods were harvested. The number of disease incidence and $\mathrm{CPB}$ infestation will demonstrate the effectiveness of the treatments. Categories of pod damage consist of mild $(<10 \%$ sticky seeds), moderate (10-50\% sticky seeds), and heavy ( $>50 \%$ sticky seeds). And grade of BPR infection on pods were mild (< $25 \%$ of rotten pods), moderate (25-50\% of rotten pods), and heavy ( $>50 \%$ of rotten pods) [26]. A number of disease incidence and pod damages was calculated by using the following formula. Data analyses using analysis of variance (ANOVA) and LSD level $\alpha=5 \%$.

Damage intensity $(I)=$
Notes:
$L=$ light damage,
$M=$ moderate damage
$H=$ heavy damage

\section{RESULTS AND DISCUSSION}

\section{A. Cocoa Pod Borer and Black Pod Rot in Cocoa}

CPB attact the plant since early pod until it's ripe. The larvae do the damage on the pod, feeding on the tissues that surround the bean and placenta, although not until attacking the beans. Symptoms of new attack usually seen on the pod surface which is yellowing, appearance of yellow-green stripes (a) and didn't any sound heard when the pods shaken. When the pods opened, the color of the rind was black and the beans often stuck together (b), wrinkled and light (Figure 1).

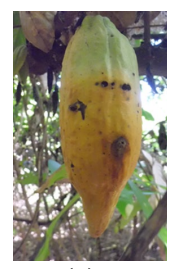

(a)

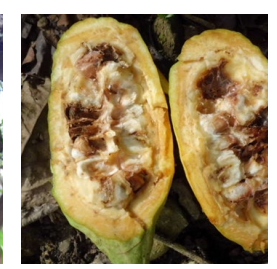

(b)

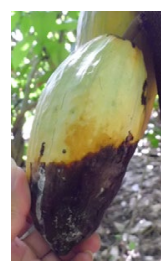

(c)

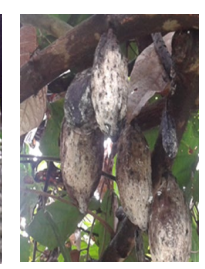

(d)
Figure 1. Symptoms of CPB $(a, b)$ and BPR $(c, d)$ in cocoa

The effect on the beans relatively small when the pod was older or almost ripe. Light infestation of CPB still results in considerable losses such as reducing the wet bean weight, yield and quality of the bean (the bean are small, the husk is increase and poor quality cocoa beans). On a moderate level infestation, the bean process just by drying without fermentation so the quality of the bean was low, the percentage of broken bean was high, high epidermis and seed coat level, low level of beans and dirty appearance of bean. Heavy damage level caused the bean can't be used because it's stuck together with the rind and difficult to separated. The symptoms of BPR infection in cacao was decay on pods surface accompanied by chocolate-brown lesions with a firm border generally start from the tip or the base of pods (c). Because of the hollow pods' shape, a deposit of water on the hollow part can help inactive propagule pathogen to germinate and hold an infection from the base. Lession from the tip caused by the hanging deposit of water at the tip of pods, the zoospores will germinate and start the infection from that part. When the pods was wet all day, lesions can form from the middle of pod. Spreading lession can develop quickly so within a few days the whole surface of pods becomes rotten, 
blackish-brown and firm (d). In a humid condition, white powder frequently appeared on the durface of pods which is a mycelium of BPR. This miselia often mixed with another pathogen. During the dry season, the propagule pathogen of BPR can persist in soil as a chlamydospore or sist with thick walls BPT were soil-borne pathogen so it can persist in soil for years. Spreading of zoospore from one plant to another can form in several ways, mainly through water splash, direct contact between infected pod with healthy pod, or helped by an animal. The rain wash was the most important spreaders because it can help the propagule spread from infected pods to healthy pods or from the soil to nearby pods. Animals can help the disease distribution because they move easily and carry sporangia of the disease to the higher and farther place.

\section{B. Intensity of Pests and Diseases}

Some things that influence the high intensity of BPR pathogen attack $(>20 \%)$ despite being treatment are the physical condition of the study site such as the height of the place from sea level, rainfall, temperature and humidity of the air. This showed that the variation in physical condition varies from place to place so that the intensity of BPR attacks will also be different. There is a strong relationship between disease progression and site height, where site height affects the level of humidity and high humidity because irrigation or rain water is the most important factor in increasing the severity and spread of BPR. These conditions cause proliferation, propagules and structural formation of pathogenic infections. Efforts are made to reduce the humidity level of the garden by preventing excess water, improving drainage and preventing trees or branches from getting wet through pruning so that sunlight can penetrate the canopy of the cacao tree [11].

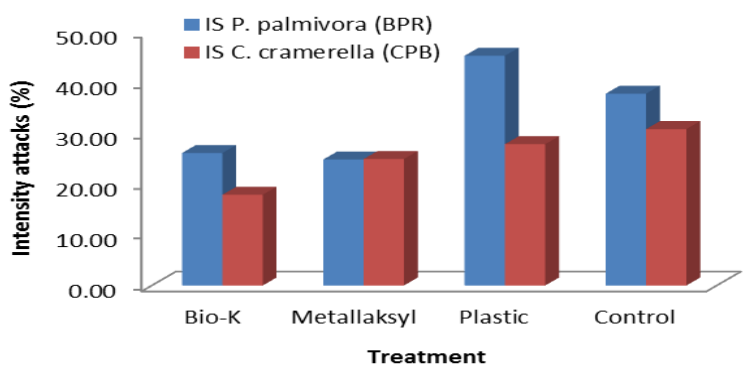

Figure 2. Intensity attacks $\mathrm{CPB}$ and $\mathrm{BPR}$ on cocoa fruids

The intensity attack of CPB on cacao fruit was different according to the type of Bio-K treatment (17.90\%), metalaxyl $(24.96 \%)$, plastic $(27.88 \%)$ and the highest in the farmer technique (control) $(30,87 \%)$ (Figure 2$)$. The intensity of pest attacks of less than $20 \%$ in the Bio-K treatment shows the ability of biopesticide technology in protecting fruits against $\mathrm{CPB}$ pest infestation was below the control threshold. This means that no other control measures are needed, especially chemicals in protecting cocoa. More than $80 \%$ of cocoa fruit can be protected from damage caused by $\mathrm{CPB}$ pests. Other pest control treatments (metalaxyl, transparent plastic and farmers) have the ability to protect cocoa pods against pests but more than $20 \%$. Disorders of CPB pests in the form of infestation (because they have to put their eggs in the cocoa fruit first and then cause damage), apparently could be inhibited by the kaolin layer contained in Biopesticides. Inhibition of kaolin was done by covering/covering the surface of the cocoa fruit so that insect pests found it difficult to land and lay their eggs.

In this study, the lowest intensity of BPR attack of $24.86 \%$ occurred in cocoa plants that were given metalaxyl treatment then followed by Bio-K treatment $(26.15 \%)$, farmers' technique $(37.86 \%)$ and plastic $(45,33 \%)$ (Figure 2 ). Metalaxyl protection maximizes the surface cover of cocoa pods and releases metalaxyl compounds so that they interfere with the growth of the BPR fungus, as well as the Bio-K treatment, but not for transparent plastic treatment because it is no better than the technique farmers. Metalaxyl protected the cocoa fruit with the ability to prevent the growth and development of BPR pathogenic fungi by inhibiting growth/infection of pathogens. Metallactyl active ingredients after being in plant tissues would undergo molecular changes so that they could cause toxic effects but still had a selective trait that was able to distinguish infected plant tissue from those not infected with pathogenic fungi and had the opportunity to reduce the intensity of disease in the field.

According to [27] the intensity of BPR attacks was 7.97$50.00 \%$ for Criollo type cocoa causing yield loss of 46.27$58.56 \%$, whereas for Forastero type cocoa the intensity of attacks was 16.17 - $48.98 \%$ lead to loss of results 31,13 $54,24 \%$. The intensity of the attacks will be accompanied by increased yield losses. The more widespread the tissue damaged by BPR fungal infections, the lower the weight of the seeds due to decay will be higher. According to [27] there were two factors identified as influencing the susceptibility of cocoa to BPR namely the level of fruit and the ability of plants to avoid BPR infections. The large number of fruits on a tree is likely to facilitate the transmission of fruit rot disease. BPR spores will more easily infect healthy fruit that is adjacent to a sick fruit. If the infected fruit is below, the spores can be transported by insects to higher fruit, if the infected fruit is tall, the sporangium will be carried by rain water to the fruit below. The statement was supported by the results of research conducted by [27] which stated that in Nigeria BPR infection by high rainfall and direct contact between sick fruit and healthy fruit reached more than $71 \%$. On the surface of the rough Criollo, cacao fruit will hold water between the skin of the cacao so that pathogens will easily germinate and penetrate the cacao fruit. Criollo cocoa pods are rough, uneven and many indentations become stagnant water so that spores will easily develop and infect fruit, in contrast to the surface of the Forastero cocoa pods are almost flat and smooth. Four treatments showed their effects on decreasing the intensity of $\mathrm{CPB}$ and BPR pathogens (Table 1). Metalaxyl application was the treatment with the lowest intensity of the BPR attack. Although it had the highest ability to inhibit the attack of 
pathogens, metalaxyl treatment was not significantly different from Bio-K but significantly different from plastic and the control. Bio-K applications had the ability to suppress the intensity of BPR relatively the same as metalaxyl whereas transparent plastic treatments have the ability to reduce the intensity of attacks lower and no better than the technique of farmers. According to [25], cloaking techniques with plastics produce disease severity twice as high as biokaolin applications every two weeks. The existence of plastic in cocoa fruit was thought to increase the micro humidity of the fruit so that it is more easily infected by pathogens.

Table 1. Effect of four treatments on the intensity attacks of PBR and CPB on cocoa fruits

\begin{tabular}{|c|c|c|c|c|}
\hline \multirow{2}{*}{ Intensity attacks (\%) } & \multicolumn{4}{|c|}{ Treatmen } \\
\cline { 2 - 5 } & Bio-K & Metallaksyl & Plastic & Control \\
\hline P. palmivora/PBR & $26,15 \mathrm{~b}$ & $24,86 \mathrm{~b}$ & $45,33 \mathrm{a}$ & $37,86 \mathrm{a}$ \\
\hline C. cramerella/CPB & $17,90 \mathrm{~b}$ & $24,86 \mathrm{a}$ & $27,88 \mathrm{a}$ & $30,87 \mathrm{a}$ \\
\hline
\end{tabular}

numbers followed by different letters in one line indicate no significant difference at the BNT 5\% level

The four treatments also showed unequal responses to the intensity of CPB pests. Biopesticide application was the only treatment reduce pest infestation below $20 \%$ and was significantly different from the other three treatments while the three were not significantly different (Table 1).

\section{Number of Fruits}

The number of cacao fruits observed decreased after treatment. The decrease in the average number of cocoa pods for each treatment, such Bio-K $(7.69 \%)$, plastic (14.29\%), metalaxyl (27.78\%) and control (62.50) \%) (Figure 3). Biopesticides provide the best results involved wit the most optimal protection against $\mathrm{CPB}$ and BPR attacks while the lowest was the way of farmers. The protection provided by Biopesticides could not be separated from its dual role, namely as a mechanical and biological protector.

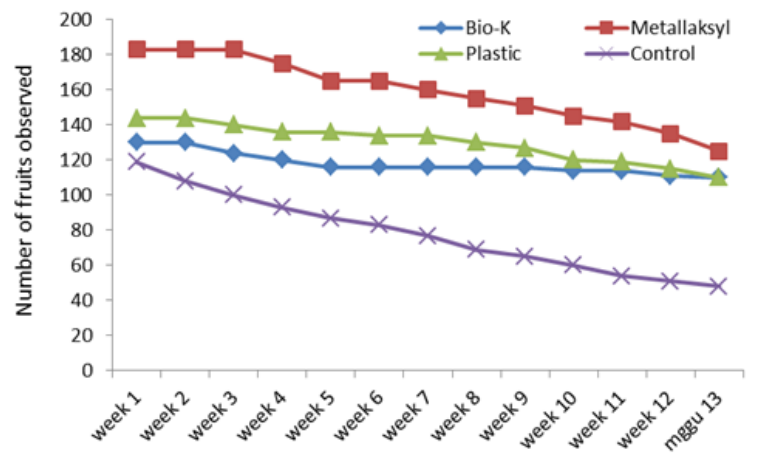

Figure 3. The number of cacao fruits observed per two weeks after treatment

Bio-K with the active ingredient of entomopathogenic fungus $B$. bassiana wre accumulated with kaolin, a type of mineral that has water-absorbing properties. Apart from being a safe mineral for consumption, kaolin is also used as a carrier agent that is inert on several pesticides while increasing the performance of several products that use microbes [24]. Bio-K coating is done by spraying on the surface of the cocoa fruit to be protected. The layer of kaolin and entomopathogenic fungus tissue of $B$. bassiana on the surface of the cocoa fruit has a dual function, in addition to being a mechanical barrier against laying pest eggs as well as biological control agents [25]. Biokaolin particles on the outer skin of cocoa can reduce the surface moisture of the cocoa fruit so that it does not create the right environmental conditions for pathogens to infect cocoa pods. Decreasing in fruit surface moisture causes the predisposition of BPR zoospores to make contact and form hyphae of penetration to penetrate fruit tissue and cause infection [25]. He added that the first weapon formed by the fungus after contact with the substrate is a hypha penetration (apresorium). Therefore, the presence of biokaolin on the surface of the cacao fruit prevents the formation of the fungus from the fungus. Biokaolin application time every two weeks is more able to prevent infection of pathogens that cause cocoa pod rot compared to other treatment applications because biokaolin can always cover cocoa pods so it is difficult to be infected by pathogens.

\section{CONCLUSION}

Symptoms attack of CPB and BPR on cocoa pods are hard to know from the initial phase, so protection of cocoa pods is needed when their lengthy is $8-10 \mathrm{~cm}$. The intensity attack of CPB on cocoa can be reduced by the innovation of biopesticide technology, while the attack of PBR can be inhibited not only by Bio-K but also by metalaxyl. Bio-K can be used as environmentally friendly protectors of cocoa fruits from $\mathrm{CPB}$ and BPR attacks.

\section{ACKNOWLEDGMENT}

Thank you, the author goes to the Agricultural Research and Development Agency, Ministry of Agriculture of the Republic of Indonesia, who has assisted funding through the North Maluku Assessment Institute Agriculture Technology. 


\section{REFERENCES}

[1] S. Zarrillo, N. Gaikwad, C. Lanaud, T. Powis, C. Viot, I. Lesur, O. Fouet, X. Argout, E. Guichoux, F. Salin, R.L. Solorzano, O. Bouchez, H. Vignes, P. Severts, J. Hurtado, A. Yepez, L. Grivetti, M. Blake, F. Valdez. The use and domestication of Theobroma cacao during the mid-Holocene in the upper Amazon. Nature Ecology \& Evolution 2, 2018, 1879-1888.

[2] W. Monteiro, U. Lopes, D. Clement. Genetic Improvement in Cocoa. In: Jain, S.M., Priyadarshan, P.M. (Eds.), Breeding Plantation Tree Crops : Tropical Species. Springer, New York, 2009, pp. 589-626.

[3] M.F. Hulme, D. Salliss, M.S. Konneh, P. Dauda, E. Witcutt, F.J. Sanderson. Improving cocoa harvest can mitigate for crop damage by wildlife in a forest-agriculture matrix. Agric., Ecosyst. Environ. 265, 2018, 236-243.

[4] R. Babin. Pest Management in Organic Cacao. In: Vacante, V., Kreiter, S. (Eds.), Handbook of Pest Management in Organic Farming. CABI, Wallingford, 2018, pp. 502-518.

[5] Directorate General of Plantations, "Statistics of cocoa plantations in 2009-2011, Indonesian Ministry of Agriculture, Jakarta, 2011.

[6] O.L. Reynolds, D. Gopurenko, P.S. Gillespie, A.C. Johnson, D. Guest, M. Woods, E. Pieterse, R. Minana, D.N. Woruba, S. Laup, C. Chang, D. Conlong. Cocoa agroecosystems and the cocoa pod borer, Conopomorpha cramerella. A review. Appendixes_1-5_final_report_hort-2018-114.pdf.

[7] F.J. Posada, I. Virdiana, M. Navies, M. PavaRipoll, P. Hebbar. Sexual dimorphism of pupae and adults of the cocoa pod borer, Conopomorpha cramerella. J Ins Sci 11:Article 52. (2011), doi:10.1673/031.011.5201.

[8] Plantation Research and Development Center, Cocoa cultivation and post harvesting, "Plantation Research and Development Center, 2010, Bogor.

[9] F.D. Babalola, O.E. Ayinde, P.W. Chirwa, D.R. Thiam. Risks and coping strategies of production and marketing of cocoa in Ondo State, Nigeria. Agroforestry Systems 91, 2017, 211-220.

[10] C. Andres, H. Comoé, A. Beerli, M. Schneider, S. Rist, J. Jacobi. Cocoa in Monoculture and Dynamic Agroforestry. In: Lichtfouse, E. (Ed.), Sustainable Agriculture Reviews: Volume 19. Springer International Publishing, Cham, 2016, pp. 121-153.

[11] J.D.L. Yen, E.K. Waters, A.J. Hamilton. Cocoa pod borer (Conopomorpha cramerella Snellen) in Papua New Guinea: Biosecurity models for New Ireland and the Autonomous Region of Bougainville. Risk Analysis, 2010, 293-309.
[12] G.N. Curry, G. Koczberski, J. Lummani, R. Nailina, E. Peter, G. McNally, O. Kuaimba. A bridge too far? The influence of socio-cultural values on the adaptation responses of smallholders to a devastating pest outbreak in cocoa. Global Environmental Change 35, 2015, 1-11.

[13] I. Valenzuela, H. Bin Purung, R.T. Roush, A.J. Hamilton. Practical yield loss models for infestation of cocoa with cocoa pod borer moth, Conopomorpha cramerella (Snellen). Crop Protection 66, 2014, 19-28.

[14] R. Ploetz, The Impact of Diseases on Cacao Production: A Global Overview. In: Bailey, B.A., Meinhardt, L.W. (Eds.), Cacao Diseases: A History of Old Enemies and New Encounters. Springer International Publishing, Cham, 2016, pp. 33-59.

[15] B.A. Bailey, L.W. Meinhardt (Eds.). Cacao Diseases: A History of Old Enemies and New Encounters. Springer International Publishing, 2016, Cham.

[16] I.Y. Opoku, M.K. Assuah, F. Aneani. Management of black pod disease of cocoa with reduced number of fungicide application and crop sanitation. African Journal of Agriculture Research 2(11), 2007, 601-604. http://www.academicjournals.org/article/article1 380898856_Opoku\%20et\%20al.pdf.

[17] Y.C. Kim, H. Jung, K.Y. Kim, S.K. Park. An effective biocontrol bioformulation against Phytophthora blight of pepper using growth mixtures of combined chitinolytic bacteria under different field conditions. Europian Journal of Plant Pathology 120, (2008), 373-382. http://dx.doi.org/10.1007/s10658-007-9227-4

[18] N.J. Nitu, Md. M.I Masum, R. Jannat, S. Sultana, Md. KA Bhuiyan. Application of chitosan and Trichoderma against soil-borne pathogens and their effect on yield of tomato (Solanum lycopersicum L.). International Journal of Biosciences 9(1), (2016), 10-24. http://dx.doi.org/10.12692/ijb/9.1.10-24.

[19] Mc Mahon P, A. Purwantara, A.W. Susilo, SriSukamto, A. Wahab, H. Purung, M. Hidayat, I. Darna, Taproni, L. Smilja, D. Guest D, P.J. Keane PJ. On-farm selection for quality and resistance to pest/diseases of cocoa in Sulawesi: (ii) quality and performance of selections against Phytophthora pod rot and Vascular-streak dieback. International Journal of Pest Management 56 (4), (2010), 351361. http://dx.doi.org/10.1080/09670874.2010.503284.

[20] A.H. Nguyen, T. Wijayanto, W. Erskine, S.J. Barker. Using green fluorescent protein sheds light on Lupinus angustifolius L. transgenic shoot development. Plant Cell Tiss. Organ Cult. 127(3), (2016), 665-674. 
http://dx.doi.org/10.1007/s11240-016-1079-1

[21] T. Wijayanto, G.R. Sadimantara, Suaib, N. Arif, D. Boer, D. Erawan, Nuryeni, Nurdin, M. Haq. Immature embryo culture accelerates soybean reproductive phase: A potential biotechnology approach for shorthening breeding cycle. International Journal of Biosciences 9(2), (2016) 37-48. http://dx.doi.org/10.12692/ijb/9.2.37-48

[22] M. Assad, M. Taufik, H.S. Gusnawaty, Asniah. Isolation, identification and ability of endophytic fungi in stimulating cocoa seed germination. International Journal of Bioscience 10(1), (2017), 270-278. http://dx.doi.org/10.12692/ijb/10.1.270278.

[23] T. Wijayanto, A. Khaeruni, M. Tufaila, Muhidin, D. Faat. The effectiveness of a biotechnologicalbased fertilizer "Biofresh" in combination with organic matters on soybean health and production. Research Journal of Pharmaceutical, Biological, and Chemical Sciences 8(2), (2017), 2808-2817. http://www.rjpbcs.com/pdf/2017 8(2)/[317].pdf.
[24] A. Wahab, T. Wijayanto, M. Taufik, L.S. Bande, H.S. Gusnawaty, M. Assad, M.D. Rahim, A.P. Firmansyah. Role of biological agents and cocoa clones to control vascular streak dieback disease (Ceratobasidium theobromae Tallbot and Keane) of cocoa plants. International Journal of Bioscience 9(3), (2016) 1-11. http://dx.doi.org/10.12692/ijb/9.3.1-11.

[25] A. Wahab, I. Kresnawaty, T. Wijayanto. Study on various control techniques to suppress the intensity of cocoa pod borer (Conopomorpha cramerella Snell) attacks in the field. International Journal of Biosciences (IJB) 10 (5), (2017), 257 264. ISSN: 2220-6655 (Print), 2222-5234 (Online) http://www.innspub.net.

[26] I. Kresnawaty, A. Budiani, A. Wahab, T.W. Darmono. Aplikasi biokaolin untuk perlindungan buah kakao dari serangan PBK, Helopeltis spp. dan Phytophthora palmivora. Menara Perkebunan, vol.78, no. 1, pp 25-31. 2010.

[27] L. Dayanti. Hubungan intensitas serangan Phytophthora palmivora dengan kehilangan hasil pada tanaman kakao (Theobroma cacao L.) di Kecamatan Ranah Batahan Kabupaten Pasaman Barat. J. Prog..Stud. Agroteknologi, Universitas Tamansiswa, pp. 1-15, 2012. 